\title{
МАРТА БЈЕЛЕТИћ
}

\section{ПРИЛОГ ПРОУЧАВАњУ ПСЛ. ГЛАГОЛА *kapati}

CoBISS: 1.01

\section{Prispevek k proučevanju psl. glagola *kapati}

$\mathrm{V}$ delu se semantično analizirajo slovanski (predvsem srbskohrvaški) kontinuanti psl. glagola *kapati, in to tistih, ki se etimološko povezujejo z lit. kãpanoti 'ubijati, klati', nusikãpanoti 'umirati, crkavati'. Rezultati analize krepijo mnenje prvotne istovetnosti s psl. *kapati in *kopati.

Ključne besede: (pra)slovanščina, baltščina, glagol, semantika, etimologija

\section{A contribution to the study of the PSI. verb *kapati}

This article offers a semantic analysis of Slavic (mostly Serbo-Croatian) derivatives of the Proto-Slavic verb *kapati, especially those etymologically connected with Lith. kãpanoti 'to kill', nusikãpanoti 'to die'. The results of this analysis support the supposition of the common origin of Proto-Slavic *kapati and *kopati.

Keywords: (Proto-)Slavic, Baltic, verb, semantics, etymology

0 Псл. глагол *kapati нема општеприхваћену етимологију. Најчешће се тумачи као ономатопеја (Berneker 487; Skok 2: 40-41; Sławski 2: 50; Machek 239-240 s.v. kapati 1; ESJS 302-303) и пореди са лит. kapnóti 'капати (о киши)' (Sławski 1.c.; Fraenkel 217). Међутим, разуђена семантика овога глагола указује и на друге могуће етимолошке везе које се, према постојећим тумачењима, гранају у два правца. Значење чеш. kapati 'вући се' указивало би на везу са лит. kópti 'пузати, милети', лет. kâpt 'пузати, милети, ићи, ходати' (Machek 240 s.v. kapati 2; Snoj 284-285 s.v. káplja), док семантика слабљења, пропадања, умирања, присутна у већини словенских језика, упућује на поређење са лит. kãpanoti ‘убијати, клати', nusikãpanoti ‘умирати, цркавати' (Fraenkel 1: 216-217; Sławski 1.c.; Bezlaj 2: 17-18 s.v. kapljáti). У овом прилогу позабавићемо се потоњим случајем.

1 Глагол *kapati у основном значењу добро је посведочен у свим словенским језицима, уп. стсл. капати 'капати', с.-х. кӓпати 'id.', ‘лити, проливати', 'прокишњавати', мак. капе 'капати', 'прокишњавати', буг. ка̀nя 'капати', слн. kápati ‘капати, цурити', чеш. kapati ‘капати’, глуж. kapać 'id.', длуж. kapaś ‘id.',

Овај прилог је резултат рада на пројекту 178007 „Етимолошка истраживања српског језика и израда Етимолошког речника српског језика“ који у целини финансира Министарство просвете, науке и технолошког развоја Републике Србије. 
пољ. kapać 'id.', pyc. кánamb 'id.', ‘сипати кап по кап’, укр. кánamu 'капати’, блр. ка́naus 'id.’ (ЭССЯ 9: 144-145 s.v. *kapati); уп. и облике на -noti-: стсл. камжти 'капнути; цурити', с.-х. ка̀нути 'капнути', 'пролити кап, сузу', ка̀nнуmи/кӓпнути 'капнути', мак. капне 'id.', буг. ка̀nна 'id.', слн. kániti, kápniti 'id.', чеш. књиж. kanouti 'капати, тећи, цурити', kápnouti 'капнути, накапати', слч. књиж. kanút’ 'цурити, тећи (нпр. о сузама)', пољ. kapnqć, заст., дијал. kanqć 'капнути', рус. ка́nнуть, ка́нуть 'id.', дијал. ка́нуть 'накапати, налити кап по кап’, ‘тећи, сливати се', 'пропуштати воду', укр. ка́нути 'капати, тећи', ка́nнymи 'капнути', дијал. ка́нути 'id.' (ЭССЯ 9: 147-148 s.v. kapnoti).

2 У већини словенских језика глагол *kapati има и друга значења, уп. срп. кӓпати 'радити без предаха, изгарати, мучити се', 'чамити, злопатити се, пропадати, скапавати, трунути' (РСА), чеш. дијал. kapat 'цркавати, липсавати', kapat dólu 'венути, пропадати (од болести)', слч. kapat' ‘цркавати', дијал. kapat' 'сатирати се тешким радом, гинути' (ЭССЯ 9: 144-145); срп. ка̀nнути) кӓпнути 'уморити се, изнемоћи, истрошити се', мак. капне 'клонути, изнурити се', буг. ка̀nна 'исцрпсти се, ослабити', 'нестати; умрети', дијал. 'изнурити се од рада', 'преморити се’, чеш. kápnouti 'нестати, умрети' (ЭССЯ 9: 147-148 s.v. *kapnoti).

Поменута значења реализују се и у префигираним облицима глагола, уп. с.-х. окапати 'измучити се', 'скапати, пропасти, сагњити', мак. окапе 'онемоћати, ослабити', буг. ока̀пя 'иструлити, сагњити', чеш. okapati 'распасти се, оронути', стслч. okapat' ‘нестати, пропасти', пољ. дијал. okapać 'нестати, пропасти, ослабити’, ‘упропастити, постати упропашћен’ (ЭССЯ 27: 101-102 s.v. *obkapati); срп. дијал. раска́nље ce 3. sg. 'дозри, презри’: Од ово́ јако́ су́нце пра́ске узре́ле, па се раскапа̇ле Црна Река (Марковић 1993), мак. раскапе се 'иструлити, иструнути, распасти се', буг. разка̀nя се 'трулити, гњити, распадати се', стслч. rozkapat'sa 'настрадати, умрети’ (ЭССЯ 33: 156-157 s.v. *orzkapati (se)); срп. дијал. отткапати 'јако озепсти, прозепсти, смрзнути се’ (РСА), буг. отка̀пвам 'гњилети, трулити, отпадати (о делу тела који се од изнурености, хладноће одузима и не може више да се покреће)', чеш. заст. odkapati 'липсати, црћи (о стоци)', 'умрети (од смрзавања)', дијал. odkapat 'умрети, црћи', стслч. odkapat' 'пасти, црћи, липсати (о стоци)', слч. разг. odkapat' ‘угинути, црћи (о људима)', дијал. 'црћи, липсати, одапети, нестати' (ЭССЯ 37: 47 s.v. *otъkapati); c.-х. скӓпати 'погинути, умрети (од муке, од јада, од каквог другог тешког стања)' (RJA), слн. skápati ‘пропасти, цркнути, угинути' (Bezlaj 2: 17 s.v. kápati), слч. skapat' ‘погинути, цркнути, нестати', пољ. skapać 'умрети, погинути', укр. ска́námися 'погинути, цркнути, нестати',1 такође буг. ска̀пвам се 'распадам се, трулим’ (Sławski 2: 55 s.v. kapieć).

1 Укр. глагол се сматра позајмљеницом из пољског или словачког (ЕСУМ 5: 265). Одговарајући облик посведочен је и у белоруском - скапе́ць 'стиснути се, смањити се, разболети се, нестати’, али је то у белоруском периферна реч (ЭСБМ 12: 112). 
3 У етимолошкој литератури преовлађује мишљење да је псл. *kapati ‘падати кап по кап’ у појединим словенским језицима секундарно развило значења ‘слабити, пропадати', ‘умирати, цркавати', настала депревербацијом од облика са префиксима $* i z b_{-},{ }^{*} s b_{-}$, који су и данас чешћи у том значењу. Семантички развој био би следећи: 'истећи кап по кап, до краја' > 'постепено западати у све горе стање (физичко, материјално); слабити, пропадати, умирати’ (Vaillant 1946: 14; цитира Sławski 2: 55 s.v. kapieć; уп. и Skok 2: 40-41; ЕСУМ 5: 265 s.v. [ска́námuся]; ЭСБМ 12: 112 s.v. скапе́u̧ь). Као аргумент за овакво тумачење Славски наводи податак да у народу постоји обичај паљења свеће да би неко ‘скапао’ као упаљена свећа (Sławski 1.c.). ${ }^{2}$ Очигледно је, дакле, да се примарним значењем псл. *kapati сматра значење 'капати, падати у капима', из којег се ланчано развијају секундарна значења 'слабити, пропадати', 'умирати, цркавати' итд. По Скоку, у питању је метафоризација исходишног значења: „У префиксалним сложеницама метафоричко значење полази од упоређења 'падати као кап, одмах, дуго, пропадати као кап у води’...“ (Skok 2: 40).

3.1 Треба нагласити да се значења 'слабити, пропадати', 'умирати, цркавати' јављају углавном у јужнословенским и западнословенским језицима. 3

Значење '(ис)трулити’ раширено је у јужнословенским језицима (осим словеначког). У с.-х. језику оно је карактеристично за говоре ји. Србије, 4 а распрострањено је и у македонском и бугарском. Будући да се труљење може схватити као један од видова пропадања, значење 'трулити' регуларно би се могло извести из 'слабити, пропадати', иако може бити и другачије мотивисано (в. Вучковић 2007: 29-30).

Значење 'смрзнути се' посведочено је превасходно у с.-х. језику (у говорима ји. Србије, Метохије и Црне Горе). 5

2 Ради се заправо о проклетству као вербалном клишеу који има за циљ да нанесе штету одређеном адресату (в. CM 270 s.v. клетва). Проклетство је превасходно вербални ритуал, и само је понекад праћено додатним радњама. У Белорусији, источној Пољској и код јужних Словена акционалне форме проклетства везане су за црквену симболику. На пример, у Бјалистоку (Пољска) жена доноси у цркву свећу, пали је, и док свећа гори, изговара речи: „A żeby ty skapał tak, jak ta świeca!““ (в. Виноградова 2008: 406). Врло је вероватно да је овде у питању само паретимолошко повезивање капања (воска) и скапавања ('пропадања, умирања').

3 Због ограниченог простора није могуће навести све потврде прикупљене за потребе овога рада. Напомињемо да је за српски језик урађена детаљна ексцерпција лексикографских извора и да ће тај материјал бити објављен на другом месту.

4 Уп. ка́ne ce impf. 'скапава се, трули’ Црна Трава (Стојановић 2010); ска́nем pf. 'иструлим' Лужница (Ћирић 1983), ска́nем се 'id.' Преображење (Златановић 1998), ска́nе 'иструли’, ска́nе се 'исквари се, пропадне, иструли, убуђа се (о воћу, поврћу)' Црна Трава (Стојановић 2010), Тимок (Кожељац 2014), Пирот (Живковић 1987).

5 Уп. ка̇ne ce impf. 'мрзне се' Каменица код Ниша (Јовановић 2004); отка́ne pf. 'озепсти’ Пирот (Златковић 2014), отка̇пље 'промрзне' Црна Река (Марковић 1986); прека́nнем 'смрзнем се' Врање (Златановић 1998), прека́nе 'много смрзне, премрзне (о рука- 
Сва поменута секундарна значења глагола *kapati заправо означавају процес слабљења, пропадања, узрокован различитим чиниоцима (глад, жеђ), умор, тежак рад, хладноћа итд.) који на крају доводи до коначне пропасти, престанка постојања. Ипак, недоумицу изазива однос секундарних значења према основном 'капати, падати у капима', јер објашњење да су она плод његове метафоризације није довољно убедљиво.

4 Као што је на почетку речено, псл. глагол *kapati у значењу 'слабити, пропадати, умирати' доводи се у везу са лит. kãpanoti ‘убијати, клати', nusikãpanoti 'умирати, цркавати'.6 Када је реч о овом глаголу, треба узети у обзир целу његову породицу, онако како је описује Френкел. Поред наведених облика, он ту сврстава још и kapùtyti ‘убити, заклати', kãpanotis, kãpurnotis, kẽpurnotis 'копрцати се, ударати рукама и ногама око себе, докопрцати се, скончати', сматрајући да ове речи стоје у вези са лит. kapóti 'сецкати' итд., али да су се укрстиле и са једном ономатопејском породицом (барем када је у питању значење 'копрцати се'), заступљеном литавским keperzúoti, kepers(t)úoti 'Ђипати, укочити се у месту, ритати се задњим ногама (о коњу)', kepersaĩs, keperzaĩs 'у скоковима, скоковито, скачући', kepresỹs 'скачући, галопирајући', išsikẽpuruoti 'с муком испузати', kepés(t)úoti ‘с муком, несигурно се вући', kèpteleti, kèpterèti 'упропастити се, пропасти, умрети'. Из летонског наводи још и kुeparât(iês), -uôt(iês), ksepuruôt(iês) 'копрцати се, с муком се пробијати, мучити се', где је $k$ z вероватно литавског порекла и одбацује поређење са чеш. с̌pár, глуж. spara, длуж. špara 'канџа' < *čъраrъ. На крају истиче да је индикативно што пољ. kapać 'капати' које је, према Бернекеру, ономатопејског порекла, у дијалектима има и значења 'умрети, пропасти, осиромашити', уп. и kapieć 'пропадати, опадати, слабити, сиромашити', блиска значењима лит. kãpanotis, nusikãpanoti (Fraenkel 1: 216-217 s.v. kãpanoti). ${ }^{7}$

4.1 Смочињски изводи лит. kãpanotis, nusikãpanoti од лит. -kàpti, -kampù, -kapaũ, посведоченог само у префигираним облицима, чија су значења за нас посебно релевантна, уп. nukàpti 'уморити се, намучити се', prikàpti 'уморити се (о коњу)', 'отупети (о секири)', 'понестати, усфалити'. Као

\footnotetext{
- ма, ногама, ушима)' Пирот (Златковић 2014), Црна Трава (Стојановић 2010); скӓnат 'озепсти, смрзнути услед велике хладноће' сев. Метохија (Букумирић 2012).

6 Треба имати у виду да лит. $n u$ - (овде ca -si- као знаком рефлексивности/интранзитивности) семантички одговара словенском ot(ъ)- (чији етимолошки еквиваленат, лит. at-, нема аблативно, него дативно значење: ateiti ‘прићи' а не 'отићи'). У том погледу, лит. nusikãpanoti семантички одговара псл. *otъkapati (в. § 2).

7 Треба напоменути да образовања горенаведених глагола не представљају регуларне творбене типове, осим глагола на -(s)noti који углавном имају деминутивно значење и означавају итеративну радњу малог интензитета, нпр. lynóti 'падати (о киши), шкропити, прскати’, ... kapnóti ‘полако сећи (дрва); шибати (о киши) итд.' : kapóti ‘ceћи’ (Otrębski 1965: 346).
} 
деривате глагола -kàpti он наводи следеће облике: kãpana 'помор, нпр. свиња', 8 одатле деноминали kãpanoti 'тешко радити, диринчити, ринтати; тешко ходати', iškãpanoti 'црћи', sukãpanoti ‘разболети се', рефл. kãpanotis 'тешко боловати, умирати, цркавати', nusikãpanoti ‘умрети, црћи'; kãparas 'крај, смрт (посебно о малим животињама и птицама)', вар. kãporas 'крај, смрт', одатле деноминали nusikãparoti, -kaparúoti 'црћи'. Облик презента kampù глагола -kàpti тумачи се уметањем назалног инфикса у основу kapкоја је у kapù, kàpti 'полако сећи, кресати (грање)', уз напомену да је семантичка страна неразјашњена (Smoczyński 2007: 254 s.v. ${ }^{\circ}$ kàpti). Френкел пак за семантичку везу између kàpti (kapiù) 'ударати, сећи' и kàpti (kampù,

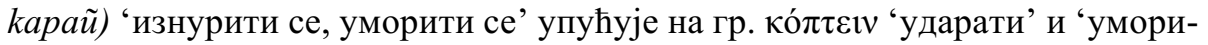
ти се’ (Fraenkel 1: 217-218 s.v. kapóti; прихвата Derksen 2015: 226).

4.2 И Дерксен разликује kapti I: лит. дијал. kàpti ‘сецнути’ (3. pres. kãpa, 3. pret. kãpè), стпр. enkopts pt. pf. pass. 'укопан, сахрањен'9 и kapti II: лит. дијал. kàpti

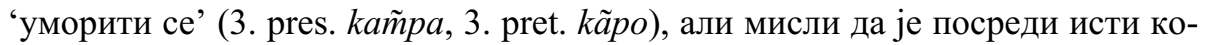
рен (Derksen 2015: 226).

Из изложеног је јасно да се лит. kãpanotis, nusikãpanoti доводи у везу са лит. kàpti 'сецнути', kapóti 'сећи'. Како је потоњи облик итератив од kàpti, који се формално у потпуности подудара са псл. kopàti (в. Smoczyński 2007: 254; Derksen 2015: 225-226), наш фокус се усмерава на могуће заједничко порекло псл. *kapati и *kopati, на шта је указао Трубачов (ЭССЯ 9: 144-145 s.v. *kapati). 10

5 Разматрајући етимологију псл. *kopati (сродног са лит. kapóti 'сећи', лет. kapât 'id.', стпрус. enkopts 'закопан, покопан' итд.), Трубачов скреће пажњу

8 Уп. слч. дијал. káp и kapál m. 'помор, липсавање (о животињама)' (SSN I 745).

9 Дерксен само сврстава под ову одредницу стпрус. enkopts а не објашњава његов вокализам, али из онога што каже о алтернацији *kāp- у претериту према *kap- у презенту излазило би да ту имамо $\bar{a}$ (Derksen 2015: 226). Говорећи о проблему рефлекаса прабалт. *ō (> лит., лет. иo) и прабалт. ${ }^{*} \bar{a}$ (> лит. $o$, лет. $\left.\bar{a}\right)$ у старопруском, Смочињски долази до закључка да се у старопруском избрисала фонолошка разлика између та два прабалтска дуга вокала а да се њихова фонетска реализација колеба између [о:] и [а:], те се пишу $о$, oa или $a$ (нпр. mothe = лит. móté, али pomatre : лит. pãmoté (пие. *mátēr) (Smoczyński 2000: $67-71)$. По томе би излазило да је у enkop $(t) s$ o или од * $\bar{a}$ или од ${ }^{*} \bar{o}$, али Смочињски у наставку указује и на случајеве када у стпрус. $o$ стоји за кратак вокал $o$ или $a$, па вероватно овде претпоставља такав случај. Мартин Кимел у LIV 555 s.v. 1. *(s)kep- 'hacken, hauen', где сврстава лит. kàpti, kapù, kàpti, kampù, kapóti, слов. kopati, skopiti, не наводи облике са дугим вокализмом (они постоје; од стсл. скөпити итератив је скаппгати, посведочен у Законоправилу Св. Саве). За облик kopati просуђује да је вероватно деноминалан, уз напомену да је презент *kopljo у словеначком и пољском секундаран (што је упитно у светлу материјала изнесеног овде у нап. 11).

10 Његово извођење *kapati ‘падати кап по кап’ из *kapati 'копати’ оспорава се зато што је то млађи, у најбољем случају познопрасловенски итератив од *kopati (ESJS 302-303). 
на творбено-морфолошки лик овог псл. глагола. Због итеративно-дуративног завршетка -ati (заједничког за слов. и балт.) очекивао би се дуги вокализам у корену (а не кратки, који је својствен глаголима типа *kopti, а који, узгред, одговара лит. kàpti). То указује на чињеницу да облик *kopajo, *kopati није примаран, као и на то да је јединство презентско-инфинитивне парадигме секундарно (без обзира на аналогно лит. kapóju, kapóti). Овај проблем није могао да реши ни Вајан који је, видевши знаке првобитне атематске промене у слн. kóplje, чеш. kope, пољ. kopie, стпрус. enkopts - оставио то питање отвореним и просто искључио презент на -je- за *kopati (Vaillant 3: 358).11 Али ако прихватимо исконску истоветност *kapati = *kopati 'наносити ударце', у облицима *kapati, *kapjo налазимо и тражено дуљење коренског вокала и старији тип промене. У формалном разликовању *kapati и *kopati огледа се њихово рано лексичко-семантичко разграничење (ЭССЯ 11: 18-20 s.v. *kopati). 12

5.1 Ови формални аргументи могу се поткрепити и семантичкима. Наиме, континуанте псл. *kopati имају и значења карактеристична за псл. *kapati, уп. ско̀nати pf. 'истрошити копањем': скопа се мотика, будак,13 у пренесеном смислу и човек: Боме се он ено на ништо скопа Лика (RJA); ско̀nати се 'смањити ce, омршавити, ископнити, ослабити': Тётка Ма́ра се скӧпа̄ла, неิма̄ штӓ вйдјети Поткозарје (Далмација 2004), зако́na ce 3. sg. ‘упропастити се': Која̇ се ло́ше ожѐни, она́ се зако́па на́живо Пирот (Златковић 2014); иско̀nати се 'пропасти, затрти се, остати без мушког порода': Не ће се свијет ископати НПосл Вук, Кад удре каква пошаст на живо, ископа се много сељачкијех кућа Богишић (PCA).

Семантика слабљења, пропадања, нестајања још је присутнија код континуаната псл. *kopbněti (se), секундарног деривата од *kopati,14 уп.

11 Вајан није имао у виду с.-х. примере, али они постоје, уп. ископӓт, ископаิм/искӧпљем: Нессмо мӧгли да искӧпљемо Косово (Елезовић 1932), такође у изразима: Бољи се копљу! 'каже се за онога који је оронуо од болести', Ђаво не оре нит копље! 'ђаво ништа не ради изузев што људе наводи на зло', Нum оре нит копље 'ништа не ради' Плав и Гусиње (Reković 2013).

12 Као семантичко-типолошка паралела могао би послужити однос два иранска корена, *1 kap-, *skap- 'расецати, копати и сл.' и *2kap-, *kaf- ‘падати, учинити да падне; спуштати (се), пуштати, бацати, рушити’ (в. Эдельман 4: 232). Едељман сумња у свођење оба та корена на ие. *(s)kep-, *(s)kop-, *(s)kap-; *(s)keb(h)-, *skob(h)-, *skab(h)- 'сећи оштрим оруђем; цепати се, расцепљивати се', али ако би то било тако, претпоставља да је њихово разилажење и претварање у хомониме морало почети веома рано и упућује на аналогна размимоилажења у словенским и балтским језицима: лет. kâpt 'дизати се, верати се' и лет. kapât 'сећи', лит. kópti 'пентрати се, извлачити се' и лит. kàpti, kapóti 'ceћи', псл. *kapati ‘капати’ и псл. *kopati (дуративно *kapati), првобитно ‘ударати’ (1.c.).

13 Уп. и скӧпак, -nка m. 'дотрајала, истрошена мотика или будак; уопште, дотрајао предмет од кога је остао само мали део’ Ужице (Цвијетић 2014), за семантику уп. лит. prikàpti 'отупети (о секири)' (в. § 4.1).

14 Псл. *kopbněti образовано је од придева *kopьnъ, који је од *kopati (в. ЭССЯ 11: 44 s.v. *kopbněti/*kopbniti; 42-44 s.v. *kopbna/*kopbno/*kopbnъ). Другачије Berneker 566; 
ко̀пнети, ијек. ко̀юети impf. 'губити снагу, свежину, слабити, мршавити, венути', 15 иско̀пнети pf. 'ишчезнути, нестати, изгубити се', 'изгубити снагу, свежину, оронути, смршати', око̀ннети 'ослабити, смршати; изгубити свежину, увенути’ (РСА), ско̀ннети 'усахнути, осушити се услед старости': Сав је већ скопнео Војводина (РСГВ), скопни' 'ослаби, смршави': Де́сина ће́рка била̀ бо́лна, мло́го скопне́ла; оста́ла са́мо ко́жа и ко́ске Црна Река (Марковић 1986).

Посебно је занимљив облик проко́nни 3. sg. pf. 'почети се мрвити (о чврстој маси)': Дрво́то п р ок о п не л о, и с т ру ле е л о [овде и даље проред М.Б.], не́ма да мо́ж да издржи́ ти́ја те́рет Пирот (Златковић 2014), који показује да се код овог глагола јавља и значење '(ис)трулити'.

6 Вратимо се глаголу *kapati. Поред облика на -ati, у словенским језицима посведочени су и облици са наставцима -е̌t $і$, нпр. пољ. kapieć (ЭССЯ 9: 146 s.v. *kapěti) и -iti, нпр. с.-х. кӓпити, 16 мак. дијал. капит, рус. дијал ка́пить итд. (id. 146-147 s.v. *kapiti). За наше излагање од посебног је значаја c.-х. глагол ука́nити, чија семантика и форма са једне стране поткрепљују тумачење о исконској истоветности *kapati и *kopati, а са друге - отварају могућности и за другачија објашњења.

6.1 Вук бележи глагол ука́пити у значењу 'убити на мјесто ( д а па дне ка о к а п )'.17 Глагол је добро посведочен у црногорским говорима, уп. ука́numи 'убити': Заслу́жијо е да га у̀ка̄пйш Ускоци (Станић 1990-1991), ука́пити (се) 'уништити (се)': Сви су му се укапили, нико му у животу није осто Прошћење (Вујичић 1995), укánum 'id.': Ријешио је да ји све укапи - Срам га било укапи ји Плав и Гусиње (Reković 2013). Ова семантика, карактеристична за лит. kãpanoti ‘убијати, клати' (в. § 4), присутна је и код континуаната псл. *kopati, уп. иско̀nати 'упропастити, уништити, затрти': Мјесто упропастити, уништити може се рећи и: ископати (Ископа сву крајину турску) Кушар; Кумичић, Св. Ћоровић (Херц.), Љубиша (ЦГ) (РСА), 18 раско̀nати 'уништити имовину': Раскопа иг син, те се

Brückner 256; Machek 275. Поред основног значења 'топити се, отапати се, кравити се (о снегу, леду)', у јужнословенским језицима забележена су и значења: 'слабити, пропадати', 'чезнути, жудети'.

15 Уп. ко̀nњ $а$ f. 'копњење, сушење, мршављење': Копња мишића [je] сушење мишића (PCA).

16 У ЭССЯ s.v. наводи се само значење 'капати', иако овај глагол значи и 'чамити, злопатити се, пропадати, скапавати, трунути’, док се облик ка́пити 'сањати у полубудном стању’ уопште не помиње.

17 Вуково семантичко објашњење прихвата Skok 2: 40.

18 Овамо свакако спада и девербал ѝскоn m. 'несрећа, зло, уништење, пропаст' ЦГ, За пропаст, уништење имамо још ове ријечи: ископ или ископање (Ова ће болест бити мој ископ) Кушар, Проти овој установи, која смиераше на изкоп славјанског богостања, устадоше ниеколико бискупах Виенац 1861 (Задар), Ако не бране народност хрватску, тад су нам отров и прави ... изкоп Павлиновић, 'смрт': Наше најсветије обичаје ... смо дужни поштовати и до ископа чувати Мале новине, Бгд. 1892, Плаћаћу до ископа, кад ми је тако суђено Ћипико (РСА). Овде би се могло поћи и од метафоричне примене основног значења 'копати', тј. 'ископати нешто са кореном > 
постарос поскиташе Прошћење (Вујичић 1995), уко̀nати 'упропастити некога': Уко̀паћу ја̂ тѐбе! Војводина (РСГВ).

Дугоузлазни акценат облика ука́пити поклапа се са акцентом итеративних облика глагола ко̀nати (иска́nати, пока́nати, ука́nати и сл.), који формално стоје у вези са лит. kuо̃pti изм. ост. 'укопавати', лет. kùopt (в. Derksen 2015: 264), стпрус. en-kopts 'покопан' (в. Smoczyński 2005: 114-115), 19 уп. и лит. kãpas, лет. kaps 'надгробна хумка', вероватно и псл. *kopъ у истом значењу (в. Лома 2013: 113 s.v. Кonopuћu). Стога би се можда облик ука́пити ‘убити' - пре него ли онако како га Вук објашњава (,да падне као кап“) - могао протумачити као каузатив од уко̀пати у значењу 'учинити да неко буде погребен, послати неког у гроб'.

6.2 Глагол ука́пити посведочен је и у значењу 'смрзнути се, нахладити се', које се јавља само код с.-х. континуаната псл. *kapati (в. § 3.1), уп. ука́пити (ce) 'нахладити се': Укапик се данас на овој студени Прошћење (Вујичић 1995), yкánum(u) ce 'id.': Ука́пијо сам се јӱтро̄с од стӱде̄ни - Ка̀ко је лёдно да се чӧек у̀ка̄пй! Мојковац (Ристић 2010), ука̄nüm ce 'id.': Ука̄пйо сæм се да̀нæс от стӱде̄, ёво су ми и руิке отёпа̄ле Васојевићи (Стијовић 1990).20 Осим тога, овај глагол има и значење које представља семантичку спону између 'слабити, пропадати; умрети, црћи' и 'смрзнути се’ (в. § 3), а то је значење 'укочити се, у к и п и т и с е, о дуз ет и с е', уп. ука́пити 'одузети се, претрнути': Еј, што си укапио, пријатељу Никшић (Ђоковић 2010), ука́пити се 'id.': Ука́пиле ми се нӧге Ускоци (Станић 1990-1991), ука́num (се) 'укочити се’ Велика (Jokić 2012), ука̄nüти $c e$ 'изгубити се, обезнанити се, укочити се': Шта сте се ту укапили, дочекајте госте Рожаје (Hadžić 2003).21 Чини се, ипак, да је семантика у оба случаја у суштини иста - 'укочити се (од хладноће)'.22

6.2.1 По свом значењу, али и форми, глагол ука́пити (ce) 'смрзнути се; укочити се' неодољиво подсећа на уки́пити се 'укрутити се, следити се, запањити

- искоренити, истребити', уп. закопати 'саградити, подићи, основати (о насељима)' (РСА). Међутим, индикативно је да се у истом значењу може употребити и девербал ӥска̄n $\mathrm{m} . / \mathrm{f}$. 'истребљење, уништење': Ти су људи гањани до изкапи Звоно 1910 (РСА).

19 В. нап. 9.

20 УП. и ска́nuт(u) ce ‘id.': Ска́пили смо се о̀но̄ јӱтро ко̀jā је стӱде̄н би́ла Мојковац (Ристић 2010).

21 УП. и чеш. заст. odkapati ‘укочити се, запрепастити се' (ЭССЯ 37: 47 s.v. *otъkapati).

22 Међусобну повезаност значења 'смрзавати се', 'укрућивати се, кочити се' и 'слабити, умирати' потврђују и следећи примери: рус. дијал. вя́знуть 'осећати хладноћу, смрзавати се', вяза́mь 'чинити тврдим, чврстим (о мразу)', укр. дијал. ков'я́знути, заков'я́знути 'кочити се; умирати', уп. и ков'я́за 'зимогрожљивац', ковя́зливий 'зимогрожљив' (Бјелетић 2006: 40, 43). Поменута значења међусобно кореспондирају и у несловенским језицима, уп. лит. kem̃ $b t i$ 'ишчезавати, пропадати, слабити, мршавити, (у)кочити се од хладноће', kaĩpti, kaipstù 'венути, пропадати, боловати' : kaĩpti, kaipiù 'кочити се од хлад-

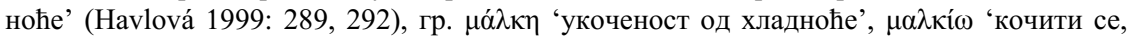

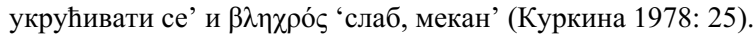


се' (Вук). Потоњи глагол се обично тумачи као деноминал од киิn 'статуа', заст. и 'људско биће, особа; људско тело, стас; раст, узраст; појава, фигура; лик, прилика; слика, портрет’. У питању је балкански хунгаризам од мађ. kép 'слика, облик, лице' < сттур. kep, које је у другом гласовном лику преко старобугарског ушло у старословенски као капь, -пи 'лик, слика', одатле капиште 'светилиште, олтар; статуа, идол', уп. и чак. капишће 'олтар' XII век, Повља, Брач, као и име ластовског острвцета Капиште (Skok 2: 38 s.v. $k a p b^{3}$; в. и ESJS 303 s.v. kapb). С обзиром на потпуни формално-семантички паралелизам облика ука́пити се : уки́пити се, ${ }^{\mathbf{2 3}}$ не може се искључити могућност да први глагол посредно чува трагове стсл. капь, -пи, с.-х. ка̂n ‘идол, божанство' (РСА), баш као и именица поткапина 'слепа пећина', ако је Скок добро изводи од синтагме под капом (Skok 1.c.).

6.2.2 Са друге стране, могућом се чини и његова веза са псл. *kypěti ‘кипети’, за семантику уп. рус. скипа́mься 'отврдњавати услед кипљења, згрудњавати се (о млеку, крви, гвожђу итд.)', рус. дијал. кипе́ть 'извирати и одмах се замрзавати (о води у зимском периоду)': речка кипит (в. Черниш 2003: 316-317). Ова претпоставка је занимљива и због тога што је *kypěti у етимолошкој вези са *kvapiti, kvapati између осталог и 'капати', а псл. *kapati ce, према неким тумачењима, изводи из *kvapati (в. нпр. Machek 239-240 s.v. kapati 1).

7 Спроведена семантичка анализа континуаната псл. глагола *kapati, пре свега оних које се доводе у етимолошку везу са лит. kãpanoti 'убијати, клати', nusikãpanoti ‘умирати, цркавати', поткрепљује мишљење о његовој исконској истоветности са псл. *kopati. У том случају, за примарно значење псл. *kapati ваљало би узети значење 'ударати'24 из којег се - као секундарна - радијално развијају значења 'падати кап по кап', 'слабити, пропадати, умирати' итд. Уосталом, семантички потенцијал значења 'ударати' омогућава развој већине горенаведених значења (в. Влајић-Поповић 2002: 32-36). 25 Тиме се коригује постојеће, широко прихваћено тумачење, према

23 Уп. и заст. кӓпӥште 'многобожачки, пагански храм или култно место' : заст. кӥпӥште 'место паганских култних обреда са киповима божанстава' (РСА), уколико није посреди Милићевићева индивидуална кованица или чак штампарска грешка уместо капиште.

24 Иако се опредељује за везу глагола *kapati са лит. kópti 'пузати, милети', лет. kâpt 'пузати, милети, ићи, ходати', Сној признаје да је поменуто тумачење привлачно јер се тако реч kâp 'апоплексија' лако објашњава из првобитног значења 'ударац', уп. нем. Schlag 'ударац' и 'кап’ (Snoj 284-285 s.v. káplja).

25 Као илустрацију наводимо секундарна значења три основна глагола ударања у с.-х. језику - бити, дерати и лупати: бӥти 'пљуштати (о киши)', у̀бити 'усмртити', 'уништи-

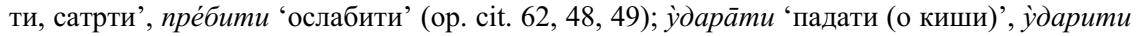


којем се значење 'слабити, пропадати, умирати' изводи непосредно из 'капати, падати у капима’ (в. § 3).

Треба нагласити да је ово само једно од могућих тумачења псл. глагола *kapati. Овом приликом у разматрање нису узете оне његове континуанте које се доводе у етимолошку везу са лит. kópti 'пузати, милети', лет. kâpt 'пузати, милети, ићи, ходати', бацајући другачије светло не само на његово порекло, већ и на развој појединих значења која се овде изводе из 'ударати'.26 Непостојање једнозначног тумачења овог прасловенског глагола указује на то да су се међу његовим 'континуантама' нашли облици различитог крајњег порекла који су се међусобно испреплитали због своје формално-семантичке сличности (в. $§ 6.2 .1$ ). Њихово прецизно разврставање на синхроном плану вероватно више и није могуће.

\section{ИЗВОРИ И ЛИТЕРАТУРА}

Бјелетић 2006 = Марта Бјелетић, Прилог проучавању псл. *vęz-, Ad fontes verborum: ucследования по этимологии и исторической семантике: к 70-летию Жанны Жановны Варбот, Москва: Индрик, 2006, 40-50.

Букумирић 2012 = Милета Букумирић, Речник говора северне Метохије, Београд: Институт за српски језик САНУ, 2012 (Монографије, 15).

Виноградова 2008 = Людмила Николаевна Виноградова, К проблеме типологии и функции магических текстов: формулы проклятий в народной культуре, XIV Международный съезд слависто:: письменность, литература и фольклор, Москва: Индрик, 2008, 397-411.

Вујичић 1995 = Милош Вујичић, Рјечник говора Прошћења (код Мојковца), Подгорица: ЦАНУ, 1995 (Посебна издања 29, Одјељење умјетности 6), 1995.

Вук = Вук Стефановић-Караџић, Српски рјечник, четврто државно издање, Београд: Државна штампарија Краљевине Југославије, 1935.

Вучковић 2007 = Марија Вучковић, Глагол о̀узнути 'ослабити, омршавети; оронути; омлохавети’ - јужнословенски дијалектизам или континуанта псл. основе *pblz-?, Шездесет година Института за српски језик САНУ: зборник радова II, Београд: Институт за српски језик САНУ, 2007, 21-33.

Далмација 2004 = Стево Далмација, Рјечник говора Поткозарја, Бања Лука: Глас српски Графика, 2004 (Рјечници).

Ђоковић 2010 = Љубомир Ђоковић, Рјечник никиићког краја, Подгорица: ЦАНУ, 2010 (Посебна издања 68, Одјељење умјетности 17).

Елезовић 1932 = Глигорије Глиша Елезовић, Речник косовско-метохиског дијалекта $1=$ Српски дијалектолошки зборник IV (1932).

ЕСУМ = Етимологічний словник украӥнськой мови 1-, ред. О. С. Мельничук, Київ: Наукова думка, 1982-.

Эдельман = Джой Иосифовна Эдельман, Этимологический словарь иранских языков 4: I-K, Москва: Издательская фирма „Восточная литература“ РАН, 2011.

‘убити', дѐрати се ‘мучити се радећи претерано тешко' (op. cit. 147, 126, 130); улу́пити ‘уништити, упропастити', лу̀пити 'ослабити, остарити' (op. cit. 182, 183) итд.

26 О томе детаљније: М. Бјелетић, К изучению чеш. диал. kapati ‘лезть’, Etymologický výzkum češtiny: z perspektivy slovanské, indoevropské i obecnělingvistické: Etymologické symposion Brno 2017 (у штампи). 
ЭСБМ = Этымалагичны слоўнік беларускай мовы 1-, ред. В. У. Мартынаў, Мінск: Навука і тэхніка, 1978-.

ЭССя = Этимологический словарь славянских языков: праславянский лексический фонд 1-, ред. О. Н. Трубачев, Москва: Наука, 1974-.

живковић 1987 = Новица Живковић, Речник пиротског говора, Пирот: Музеј Понишавља Пирот, 1987.

Златановић 1998 = Момчило Златановић, Речник говора јужне Србије: провиниијализми, дијалектизми, варваризми и др., Врање: Учитељски факултет, 1998.

Златковић 2014 = Драгољуб Златковић, Речник пиротског говора I-II, Београд: Службени гласник, 2014.

Јовановић 2004 = Властимир Јовановић, Речник села Каменице код Ниша, Српски дијалектолошки зборник LI (2004), 313-688.

Кожељац 2014 = Љубиша Рајковић Кожељац, Речник тимочког говора, Неготин: Књижевно-издавачко друштво Лексика, 2014.

Куркина 1978 = Любовь Викторовна Куркина, Русск. диал. малохольный, сверёжий, Этимологические исследования (Свердловск) 1978, $23-27$.

Лома 2013 = Александар Лома, Топонимија Бањске хрисовуље: ка осмишьењу старосрпског топономастичког речника и бољем познавању општесловенских именословних образаиа, Београд: САНУ, 2013 (Библиотека Ономатолошких прилога 2).

Марковић 1986 = Миодраг Марковић, Речник народног говора у Црној Реци, Српски дијалектолошки зборник XXXII (1986), 245-500.

Марковић 1993 = Миодраг Марковић, Речник народног говора у Црној Реци II, Српски дијалектолошки зборник XXXIX (1993), 149-398.

Ристић 2010 = Данијела Ристић, Рјечник говора околине Мојковиа, Подгорица: ЦАНУ, 2010 (Институт за језик и књижевност „Петар II Петровић Његош“, Рјечници 5).

PCA = Речник српскохрватског књижевног и народног језика 1-, Београд: САНУ - Институт за српски језик САНУ, 1959-.

PСгВ = Речник српских говора Војводине 1-10, Нови Сад: Матица српска, 2000-2010.

$\mathbf{C M}=$ Словенска митологија: енциклопедијски речник, ред. Светлана М. Толстој - Љубинко Раденковић, Београд: Zepter Book World, 2001.

Станић 1990-1991 = Милија Станић, Ускочки речник 1-2, Београд: Научна књига, 1990-1991.

Стијовић 1990 = Рада Стијовић, Из лексике Васојевића, Српски дијалектолошки зборник XXXVI (1990), 121-380.

Стојановић 2010 = Радосав Стојановић, Црнотравски речник = Српски дијалектолошки зборник LVII (2010).

Ћирић 1983 = Љубисав Ћирић, Говор Лужнице, Српски дијалектолошки зборник XXIX (1983), 7-191 (речник 125-164).

Цвијетић 2014 = Ратомир Цвијетић, Речник ужичког говора, Београд: Службени гласник Крагујевац: Универзитет у Крагујевцу - Ужице: Учитељски факултет у Ужицу, 2014.

Черниш 2003 = Тетяна Олександрівна Черниш, Слов'янська лексика в історико-етимологічному висвітленні: гніздовий підхід, Київ: Київський національний університет ім. Тараса Шевченка, 2003.

Berneker $=$ Erich Berneker, Slavisches etymologisches Wörterbuch 1, Heidelberg: Carl Winter's Universitätsbuchhandlung, 1908-1913.

Bezlaj = France Bezlaj, Etimološki slovar slovenskega jezika I-V, Ljubljana: SAZU, 1976-2007.

Brückner = Aleksander Brückner, Stownik etymologiczny języka polskiego, Warszawa: Wiedza Powszechna, 1957.

Derksen 2015 = Rick Derksen, Etymological Dictionary of the Baltic Inherited Lexicon, Leiden Boston: Brill, 2015.

ESJS = Etymologický slovník jazyka staroslověnského 1-, red. E. Havlová, Praha 1989-.

Fraenkel $=$ Ernst Fraenkel, Litauisches etymologisches Wörterbuch I-II, Heidelberg - Göttingen: Carl Winter - Vandenhoeck \& Ruprecht, 1962-1965. 
Hadžić 2003 = Ibrahim Hadžić, Rožajski rječnik: građa za diferencijalni rječnik narodnog govora rožajskog kraja, Rožaje: Kulturni centar Rožaje, 2003.

Havlová 1999 = Eva Havlová, Komplexní situace jako sémantické východisko při vzniku slovanských slov (na př́kladu sémantického východiska 'chřadnout'), Slavia 68 (1999), 287-294.

Jokić 2012 = Branko Jokić, Rječnik veličkoga govora, Podgorica: Institut za crnogorski jezik i književnost, 2012 (Lexicographia 1).

Machek = Václav Machek, Etymologický slovník jazyka českého, Praha: Academia, Nakladatelství Československé akademie věd, 21968.

Otrębski 1965 = Jan Otrębski, Gramatyka języka litewskiego II, Warszawa: Państwowe Wydawnictwo Naukowe, 1965.

Reković 2013 = Ibrahim Reković, Rječnik plavsko-gusinjskoga govora, Podgorica: Institut za crnogorski jezik i književnost, 2013 (Lexicographia 3).

RJA = Rječnik hrvatskoga ili srpskoga jezika I-XXIII, Zagreb: JAZU, 1880-1976.

Skok = Petar Skok, Etimologijski rječnik hrvatskoga ili srpskoga jezika I-IV, Zagreb: JAZU, 19711974.

Sławski = Franciszek Sławski, Słownik etymologiczny języka polskiego 1-, Kraków: Nakładem Towarzystwa Miłośników Języka Polskiego, 1952-.

Smoczyński 2000 = Wojciech Smoczyński, Untersuchungen zum deutschen Lehngut im Altpreussischen, Kraków: Wydawnictwo Uniwersytetu Jagiellońskiego, 2000.

Smoczyński 2005 = Wojciech Smoczyński, Lexikon der altpreussischen Verben, Innsbruck: Institut der Sprachen und Literaturen der Universität Innsbruck, 2005.

Smoczyński 2007 = Wojciech Smoczyński, Stownik etymologiczny języka litewskiego, Wilno: Uniwersytet Wileński, 2007.

Snoj = Marko Snoj, Slovenski etimološki slovar, Ljubljana: Založba ZRC, ZRC SAZU, ${ }^{32016 .}$

SSN = Slovník slovenských nárečí, I-, Bratislava: Veda, vydavatel'stvo Slovenskej akadémie vied, 1994-.

Vaillant = André Vaillant, Grammaire comparée des langues slaves I-IV, Lyon - Paris, 1950-1974.

Vaillant 1946 = André Vaillant, La déprévarbation, Revue des études slaves 22 (1946), no 1, 5-45.

\section{PovzeteK}

\section{Prispevek k proučevanju psl. glagola *kapati}

$\mathrm{V}$ delu se semantično analizirajo kontinuanti psl. glagola *kapati, predvsem tisti, ki se etimološko povezujejo z lit. kãpanoti 'ubijati, klati', nusikãpanoti 'umirati, crkavati'. Rezultati analize govorijo za skupni izvor psl. *kapati in *kopati, kar pomeni, da je psl. * kapati prvotno pomenilo 'udarjati', iz tega pa so se radialno razvili pomeni 'padati kaplja za kapljo', 'slabeti, propadati, umirati' itd. Izrecno pa se izvzemajo tisti kontinuanti psl. *kapati, ki se etimološko povezujejo z lit. kópti 'plaziti se, lesti', let. kâpt 'plaziti se, lesti, iti, hoditi', pri tem pa mečejo drugačno luč ne le na njegov izvor, ampak tudi na razvoj posameznih pomenov, ki se tu izvajajo iz 'udarjati'. Odsotnost enoumne razlage tega praslovanskega glagola kaže na to, da so se med njegovimi kontinuanti znašle oblike različnih izvorov in se med sabo prepletle zavoljo svoje formalno-semantične podobnosti. Njihovo precizno razvrščanje $v$ sinhroni ravnini verjetno tudi ni več mogoče. 